\section{H anyang Medical R evi ews}

Hanyang Med Rev 2013;33:154-159

http://dx.doi.org/10.7599/hmr.2013.33.3.154

pISSN 1738-429X eISSN 2234-4446

\section{간의 허혈-재관류 손상 측정 도구로서 간 조직 생체 전기 저항의 변화가 가지는 의미와 원인}

윤성수

영남대학교 의과대학 외과학교실

\title{
Significance of Bioelectrical Impedance Change after Ischemia and Reperfusion Injury in Liver and What it Causes?
}

\author{
Sung Su Yun \\ Department of Surgery, Yeungnam University College of Medicine, Daegu, Korea
}

\begin{abstract}
Purpose: Ischemia and reperfusion (I/R) injury is a major cause of hepatic failure after liver surgery, but there is no direct method to monitor it in real-time (like an ECG in heart disease) during surgery. Recently we found the possible role of bioelectrical impedance (BEI) to monitor I/R injury in liver, but the mechanism responsible for ischemia-related BEI changes has not been clearly determined. Methods: The authors used a LCR meter to quantify BEI changes at $0.12 \mathrm{KHz}$. Livers were subjected to $70 \%$ partial ischemia for 120 minutes, and ATP content, cation changes in extracellular fluid (ECF; determined using an in vivo intracellular microdialysis technique), hepatocyte sizes, and histological changes were then examined. Results: Liver tissue BEl was found to increase gradually during the first 60 minutes of ischemia and then tended to plateau. During the same period, intracellular ATP content decreased to below $20 \%$ of the baseline level, $\left[\mathrm{Na}^{+}\right]$in ECF decreased from $150.4 \pm 3.8$ to $97.8 \pm 10.6 \mathrm{mmol} / \mathrm{L}$, and $\left[\mathrm{K}^{+}\right]$in $E C F$ increased from $7.5 \pm 0.3$ to $34.3 \pm 5.5 \mathrm{mmol} / \mathrm{L}$ during the first 60 minutes of ischemia. Hepatocyte diameter increased by approximately $20 \%$ during the first 60 minutes of ischemia. Conclusion: This study suggests that BEl changes during hepatic ischemia are probably caused by sodium and potassium concentration changes in the ECF due to reduced intracellular ATP content.
\end{abstract}

Key Words: Electric Impedance; Adenosine Triphosphate; Liver; Microdialysis; Cations

\author{
Correspondence to: Sung Su Yun \\ 우705-717, 대구광역시 남구 현충로 170 , \\ 영남대학병원 외과 \\ Department of Surgery, Yeungnam Uni- \\ versity Hospital, 170 Hyeonchung-ro, \\ Nam-gu, Daegu 705-717, Korea \\ Tel: +82-53-620-2590 \\ Fax: +82-53-624-1213 \\ E-mail: ssyun@med.yu.ac.kr \\ Received 26 May 2013 \\ Revised 26 July 2013 \\ Accepted 4 August 2013 \\ This is an Open Access article distributed under \\ the terms of the Creative Commons Attribution \\ Non-Commercial License (http://creativecom- \\ mons.org/licenses/by-nc/3.0) which permits un- \\ restricted non-commercial use, distribution, and \\ reproduction in any medium, provided the origi- \\ nal work is properly cited.
}

\section{서 론}

최근 간절제술 및 간이식술의 성적이 획기적으로 개선되었지만, 수술 후 간기능부전에 의한 사망은 여전히 심각한 문제로 남아 있 으며, 주요 원인은 수술 중 받은 허혈 및 재관류 손상으로 알려져 있 다. 간 수술 중에 발생하는 허혈 및 재관류 손상은 피할 수 없는 과 정으로, 간절제술 시는 간의 구동과정(hepatic mobilization)과 출 혈을 줄이기 위한 인위적 혈류폐쇄가 주원인이 되며, 간이식 중에 는 이식 간의 적출에서 문합에 이르기까지의 허혈 손상과 문합 후 재관류에 따르는 손상에 기인한다.

간 수술 전 외과의가 시행하는 간 예비능 검사는 다양한 종류가
소개되어 있다[1-5].

그러나간수술 중에 발생하는 허혈 및 재관류 손상은 수술 후간 기능부전과 직접 연계되어, 수술 후 예후를 결정하는 큰 요소 임에 도 불구하고, 수술 중 이를 실시간으로 측정할 수 있는 적절한 방법 이 없다.

저자는 간 허혈 손상 시 간의 생체 전기 저항(bioelectrical impedance, $\mathrm{BI}$ )이 변화한다는 사실에 착안하여[6-10], 간의 허혈-재 관류 손상과 간 조직 생체 전기 저항 변화와의 상관관계와 허혈-재 관류 손상을 조직학적 측면에서 관찰하고, 수술 중 간의 허혈-재관 류 손상 측정 도구로서 간 조직 생체 전기 저항의 변화가 가지는 의 미와 원인을 규명하는 실험들을 진행하였다. 


\section{1. 간의 허혈-재관류 손상과 간 조직 생체 전기 저항 변화측정}

생체 전기 저항의 측정은 직경 $0.2 \mathrm{~mm}$ 의 백금으로 도금된 단극 전극(mono-polar needle) 2 개를 $10 \mathrm{~mm}$ 간격으로 간 조직에 삽입 고정시킨 후, LCR meter (GS-4311B, ANDO, Japan)를 이용하여 양극 간에 다양한 교류전류 $(120 \mathrm{~Hz}-100 \mathrm{KHz})$ 를 인가하여 5 분 간 격으로 연속 관찰하였다.

\section{2. 간의 허혈 손상을 가장 정확히 예견 하는 주파수 대역}

간에 허혈 손상을 유도 후 $120 \mathrm{~Hz}, 1.2 \mathrm{KHz}, 12 \mathrm{KHz}, 62.5 \mathrm{KHz}$ 및 $100 \mathrm{KHz}$ 을 인가하여 생체 전기 저항의 변화를 관찰하였다. 주파수 가 높을수록 간의 허혈 손상을 나타내는 변별력이 떨어졌고, 아래 의 실험 3 와 4 를 위한주파수를 $120 \mathrm{~Hz}$ 로 정할 수 있었다(Fig. 1).

\section{3. 허혈-재관류 후 생체 전기 저항의 변화 관찰}

간 조직에 $120 \mathrm{~Hz}$ 의 교류전류를 인가하고 30 분간 허혈 손상을 유도하고 재관류 후 20 분 동안 연속하여 생체 전기 저항의 변화를 관찰하였다. 허혈 유도 전, 유도 후 $5,10,15,20,25$ 및 30 분의 생체 전기 저항은 각각 $4.13 \pm 0.22$ (Mean $\pm \mathrm{SD}$; 이하 생략), $4.57 \pm 0.22$, $4.89 \pm 0.38,5.57 \pm 0.77,6.19 \pm 0.72,7.18 \pm 0.65,8.58 \pm 0.69 \kappa \Omega$ 으 로 점차적인 상승을 보였으며, 재관류 후 $5,10,15$ 및 20 분 후의 생 체 전기 저항은 $7.57 \pm 0.56,7.02 \pm 0.45,6.52 \pm 0.58$ 및 $6.29 \pm 0.61$ $\kappa \Omega$ 으로 감소하는 경향을 보였다(Fig. 2).

\section{2 시간 연속 간의 허혈 손상을 유도 후 생체 전기 저항 변화 관찰}

간 조직에 $120 \mathrm{~Hz}$ 의 교류전류를 인가하고 2시간 동안 허혈 손상 을 유도한 후 연속하여 생체 전기 저항을 관찰한 결과 허혈 유도 후 50 분간은 생체 전기 저항의 지속적인 상승이 관찰되었으나, 1 시간 을 전후 하여 plateau를 형성하는 경향을 보였다(Fig. 3).

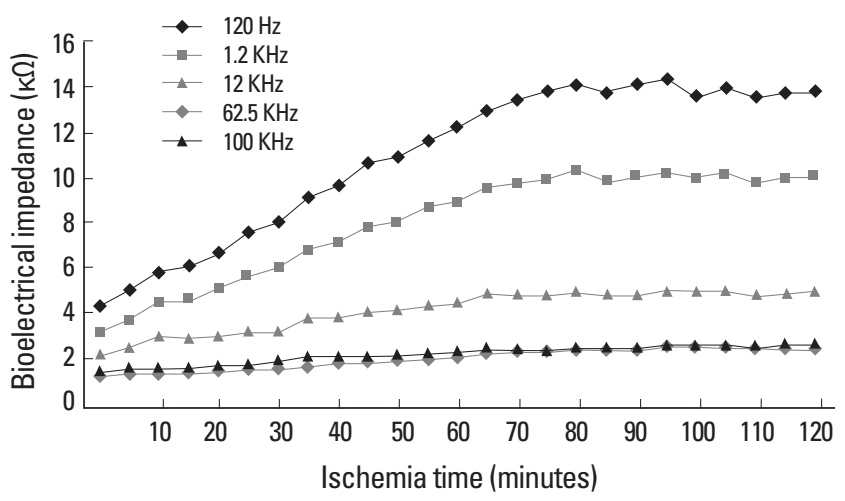

Fig. 1. Changes of bioelectrical impedance in liver during ischemia according to frequency $120 \mathrm{~Hz}$ to $100 \mathrm{KHz}(n=5)$. Ref. 20 with permission from the Korean Association of Hepato-Biliary and Pancreas Surgery.

\section{2시간 허혈 중 간 조직 손상 및 간세포 생존}

1) Adenosine triphosphate (ATP) 변화

간 중엽 말단 부위에서 $100 \mathrm{mg}$ 의 조직을 절제하여 $10 \%$ cold perchloric acid buffer로 10 배 희석하고 가위로 잘게 자른 다음 Ultraturax T-25 (Janke and Kunkel, Germany)를 이용하여 균질화하여 $-70^{\circ} \mathrm{C}$ 냉동고(deep freezer)에 냉동 보관한 후 Khan이 제안한 방법 [11]으로 일괄 측정하였다.

120 분 허혈 과정에서 30 분 간격으로 채취한 간 조직내의 ATP는 각각 $0.5 \pm 0.1,0.3 \pm 0.1,0.3 \pm 0.1,0.2 \pm 0.1$ ( $\mu \mathrm{mol} / \mathrm{g}$ wet wt, Mean

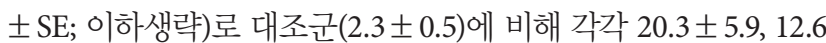
$\pm 2.0,11.3 \pm 2.9,8.9 \pm 2.3 \%$ 로 의미 있게 $(\mathrm{P}<0.05)$ 감소하였다. 30 분 허혈에 비하여 60 분, 90 분 및 120 분 허혈 손상 후 ATP는 의미 있 게 $(\mathrm{P}<0.05)$ 감소하였지만, 60 분, 90 분 및 120 분 허혈 사이에는 의 미 있는 변화가 없었다(Fig. 4).

\section{2) 지방산 대사 능력}

간 조직 $500 \mathrm{mg}$ 정도를 절제하여 SETH buffer (260 mM sucrose, $1 \mathrm{mM}$ EDTA, $10 \mathrm{mM}$ Tris-HCl, pH 7.4)로 20배 희석하여 Kim 등 이 제안한 방법[12]으로 측정하였다.

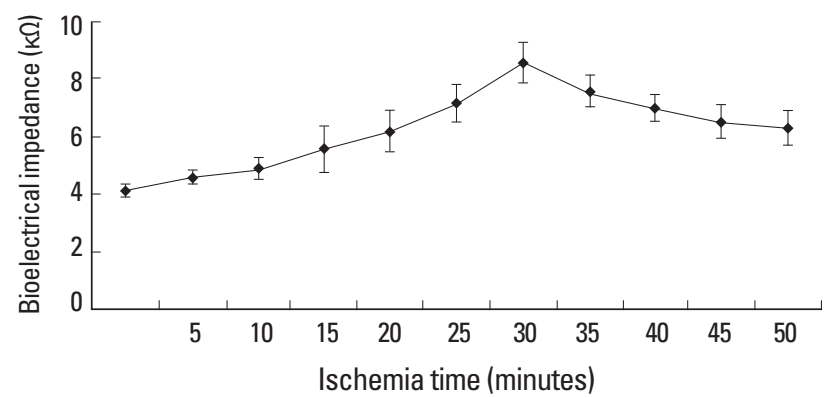

Fig. 2. Change of bioelectrical impedance in liver during 30 minutes ischemia and 20 minutes reperfusion at $120 \mathrm{~Hz}$. Bars represent means values $\pm S D(n=5)$. Ref. 20 with permission from the Korean Association of Hepato-Biliary and Pancreas Surgery.

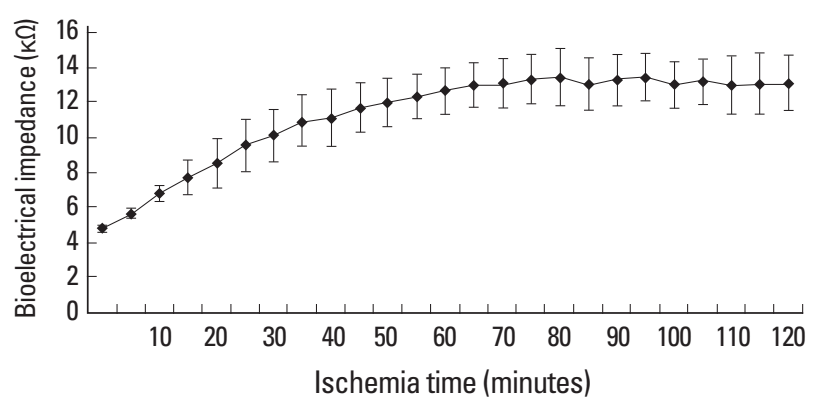

Fig. 3. Change of bioelectrical impedance in liver during 120 minutes ischemia. Bars represent means values $\pm S D(n=5)$. Ref. 20 with permission from the Korean Association of Hepato-Biliary and Pancreas Surgery. 


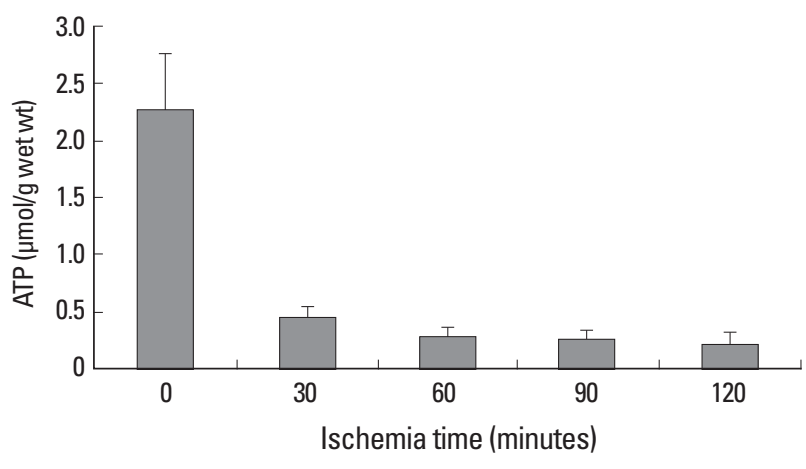

Fig. 4. ATP content of the ischemic liver at 30 minutes interval during 120 minutes ischemia. Ref. 22 with permission from Korean Surgical Society.

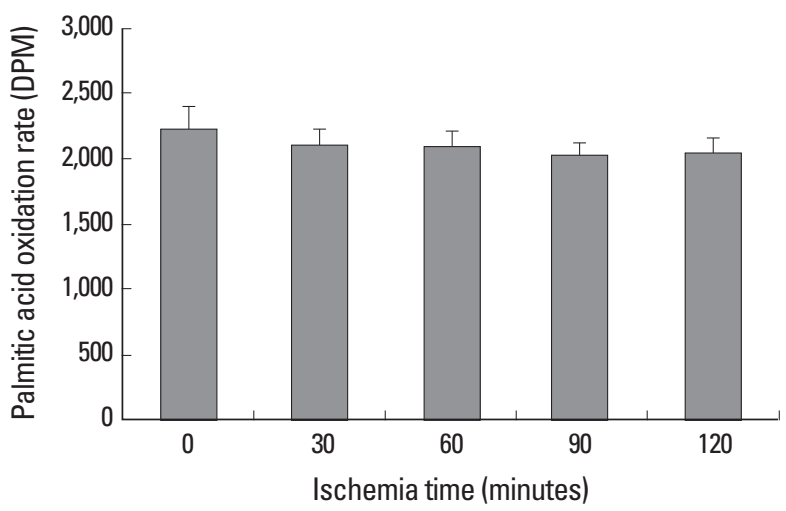

Fig. 5. Palmitic acid oxidation rate of the ischemic liver at 30 minutes interval during 120 minutes ischemia. Ref. 22 with permission from Korean Surgical Society.

120 분 허혈 손상 중 30 분 간격으로 채취한 간 조직에서 지방산 대사율은 각각 $2,114 \pm 117.1,2,094 \pm 127.4,2,030 \pm 97.5$ 및 2,050 $\pm 116.9 \mathrm{DPM}$ 로 대조군 $2,226 \pm 172.6$ 에 비해 의미 있는 대사율의 변화를 볼 수는 없었다(Fig. 5).

\section{3) 조직소견}

간 조직을 절취하여 $5 \mathrm{~mm}$ 의 두께로 자른 후 $10 \%$ 중성포르말린 에 고정시켜서 파라핀에 포매하여 $4 \mu \mathrm{m}$ 두께로 박절하여 통상적인 방법으로 hematoxylin and eosin (H\&E) 염색을 하였으며, terminal deoxynucleotidyl transferase dUTP nick end labeling (TUNEL) 염색은 ApopTag Peroxidase In Situ Apoptosis Detection Kit (S7100, Chemicon International, Inc., MA, USA)을 사용하였으며 제작하 였다. 조직손상의 정도는 미국립보건원(National Institutes of Health, $\mathrm{NIH}$ )에서 제공하는 image J 프로그램을 사용하여 전체 간엽과 조직괴사의 상대적인 면적을 구한 후 퍼센트로 나타내었다.

120 분 허혈 손상 중 30 분 간격으로 조직을 부분 절제하여 관찰 한 조직 소견에서(H\&E 및 TUNEL stain: $n=5)$ 는 의미있는 변화를
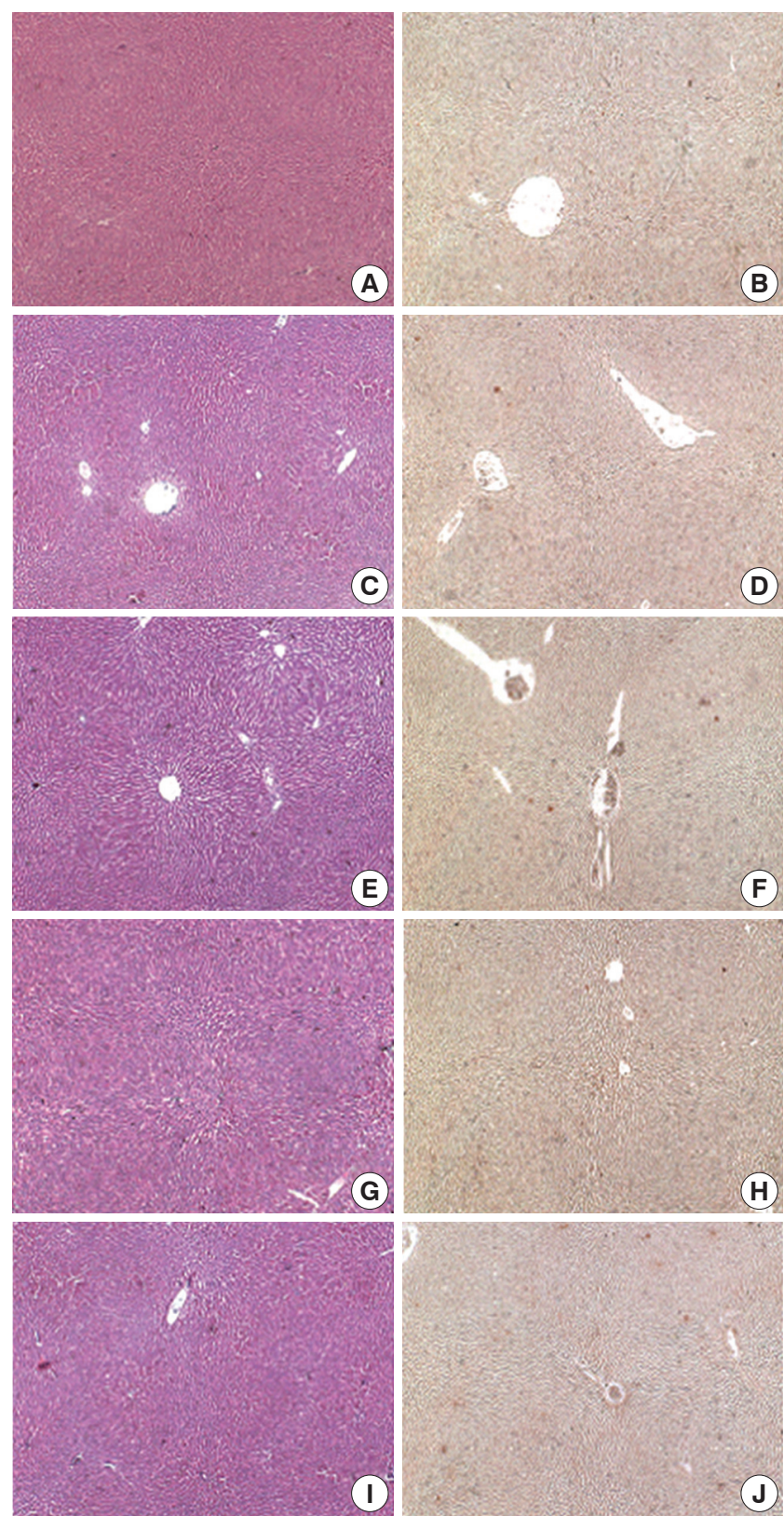

Fig. 6. Microscopic findings of the ischemic liver during 120 minutes ischemia. Ref. 22 with permission from Korean Surgical Society. (A, C, $E, G, I)$ hematoxylin eosin (H\&E) stain $\times 40,(B, D, F, H, J)$ TUNEL stain $\times$ 40. (A, B) control, (C, D) 30 minutes ischemia, $(E, F) 60$ minutes ischemia, $(G, H) 90$ minutes ischemia, $(I, J) 120$ minutes ischemia.

찾아 볼수가 없었으나(Fig. 6) 간세포의 직경은 60 분 허혈 후 약 $20 \%$ 정도 증가 하였고 그 이후에는 큰 변화가 없었다(Fig. 7).

\section{6. 간 세포외액(extracellular fluid)에서의 전해질 측정}

허혈 손상중 간의 생체 전기저항이 변화하는 원인을 규명하기 위하여 microdialysis 기법으로 zero net flux (ZNF) curve를 그려 


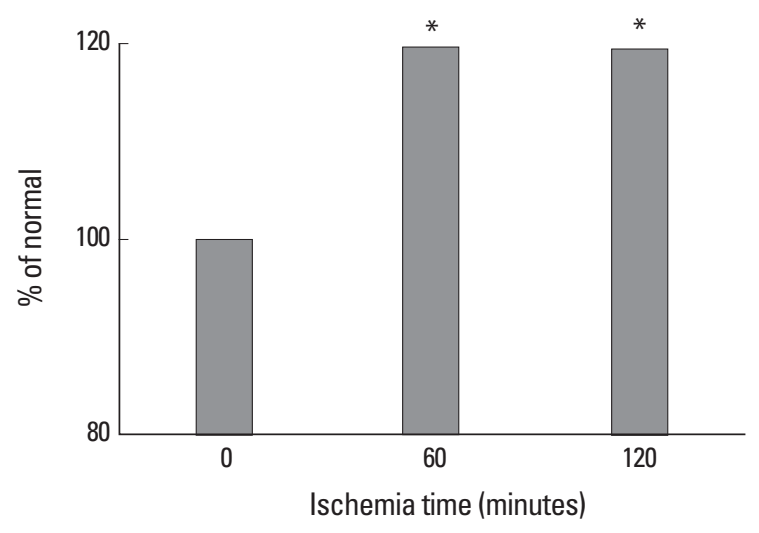

Fig. 7. Changes in hepatocyte diameter during 120 minutes of ischemia. ${ }^{*} \mathrm{P}<0.05$ vs 0 minutes (non-ischemia). Ref. 14 with permission from Korean Surgical Society.

서 간 세포외액에서 전해질을 측정하였다[13,14]. Microdialysis probe (CMA 30 Linear Microdialysis Probe, CMA/Microdialysis, Solna, Sweden)는 cuprophane membrane (length $10 \mathrm{~mm}$, molecular cut off 6000 Daltons, outer diameter $0.24 \mathrm{~mm}$ )을 가진 것으로 perfusion pump (CMA 102 Microdialysis Pump, CMA/Microdialysis AB, Solna, Sweden)를 연결하여 사용하였다.

허혈 0, 0-30, 30-60, 60-90, and 90-120분 동안의 간세포 외액의 $\left[\mathrm{Na}^{+}\right](\mathrm{mM})$ 은 $150.4 \pm 3.8,128.9 \pm 5.1,97.8 \pm 10.6,90.7 \pm 4.9$ 와 $88.7 \pm 5.0$ 였으며 $\left[\mathrm{K}^{+}\right](\mathrm{mM})$ 은 $7.5 \pm 0.3,22.1 \pm 0.7,34.3 \pm 5.5,40.4$ \pm 7.0 와 $48.3 \pm 1.7$ 로 허혈 유도 후 $\left[\mathrm{Na}^{+}\right]$은 의미있게 $(\mathrm{P}<0.05)$ 감소 하였으며, [K+ $\mathrm{K}^{+}$은 의미있게 $(\mathrm{P}<0.05)$ 증가하였다(Fig. 8).

\section{7. 생체 전기저항의 변화와 간세포 외액의 전해질과의 상관 관계}

간의 생체 전기저항은 허혈 유도 $30,60,90$ 및 120 분에 $3.1 \pm 0.2$, $8.1 \pm 0.3,10.1 \pm 0.5,10.8 \pm 0.8$ 및 $11.3 \pm 0.9 \kappa \Omega$ 로 증가하였고 간 세포외액의 $\left[\mathrm{Na}^{+}\right]$과 $\left[\mathrm{K}^{+}\right]$의 합은 $157.8 \pm 3.8,151.4 \pm 5.9,135.7 \pm$ 7.6, $131.0 \pm 6.2$ 및 $137.0 \pm 6.3 \mathrm{mM}$ 로 감소하였다(Fig. 9).

\section{고 찰}

간절제술 중이나 간이식술 중에는 허혈 및 재관류 손상이 발생 하게 되고, 수술 후 간기능부전과 연계되어, 수술의 예후를 결정하 는 중요한 인자가 된다. 그러나 현재 사용 중인 간 예비능 측정법(indocyanin green test, redox tolerance index, aminophyllin breath test 등)들은[1-5] 수술 중 시시각각 변화는 허혈 및 재관류 손상을 실시간으로 측정하기에는 문제점이 있어, 현재 간 수술은 경험에 의한 자료에 근거하여 진행되고 있다.

필자는 간에서 허혈 및 재관류 손상을 유도하고, 간 조직 내에 미 세교류 전류를 인가하여 생체 전기 저항을 측정하고, 조직의 괴사

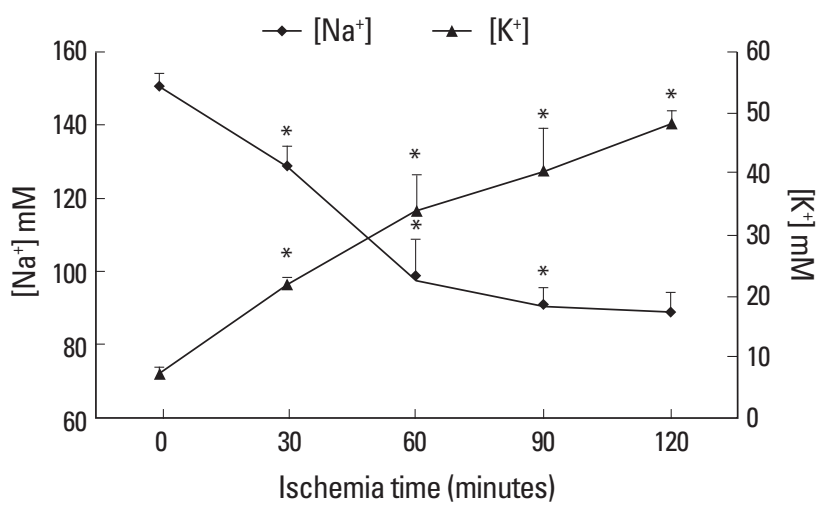

Fig. 8. Changes in $\mathrm{ECF}\left[\mathrm{Na}^{+}\right]$and $\left[\mathrm{K}^{+}\right]$in liver tissues in vivo during 120 minutes of ischemia. ${ }^{*} \mathrm{P}<0.05$ vs 0 minutes (non-ischemia). Ref. 14 with permission from Korean Surgical Society.

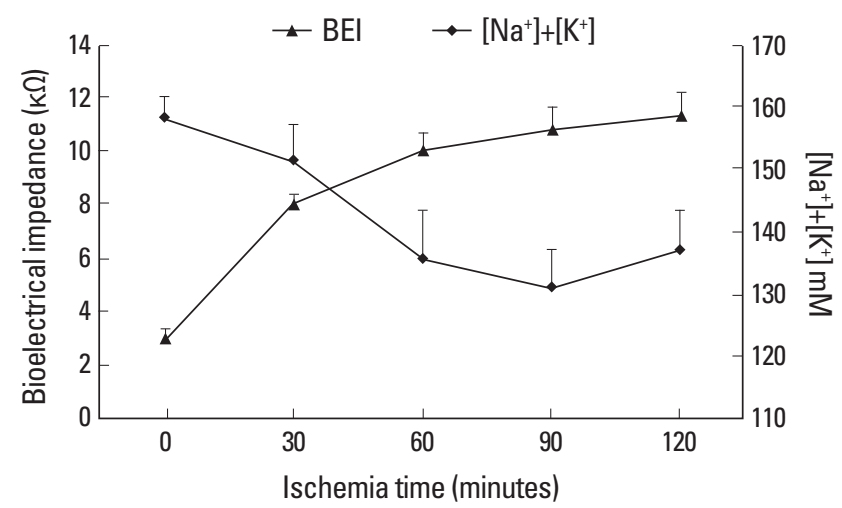

Fig. 9. The correlation between $\mathrm{BEl}$ and summed $\left[\mathrm{Na}^{+}\right]$and $\left[\mathrm{K}^{+}\right]$in liver tissue ECF in vivo. Ref. 14 with permission from Korean Surgical Society.

및 생존력(viability) 여부와의 상관관계와 생체 전기 저항이 변하 는 원인을 규명하기 위하여 연구를 하였다.

생체 전기 저항은 세포외 저항(extracellular resistance), 세포 내 저항(intracellular resistance)과 세포막 전기용량(cell membrane capacitance)에 따라 결정되는데 허혈 손상은 조직 내 생체 전기 저 항의 변화를 초래한다. 연구자의 실험에서 사용한 여러 가지 주파 수 $(120 \mathrm{~Hz}-100 \mathrm{KHz})$ 중, 생체 전기 저항은 저주파 영역에서 고주파 영역 보다 허혈 손상을 변별력 있게 나타내어 주었으며(Fig. 1-3), 이 는 타 연구자들의 관찰과 일치하였다[7-9]. 허혈 손상에 관계하는 인자에는 ATP의 부족, 자가 용해 기전의 활성화, 세포의 산성화, 과 산화에 의한 세포막 투과성의 증가, 미토콘드리아의 기능 부전 등 이 원인으로 거론되고 있으나[15-17], 아직까지 허혈 손상 시 생체 전기 저항의 상승에 관한 기전은 확실히 알려져 있지 않고 있었다.

그러나 저주파가 가지는 생체 조직 내의 흐름, 즉, 저주파는 세포 막을 통과하지 못하고 굴절하여 세포조직외액을 따라 흐른다는 이 
론에 근거하고[18], 생체 전기 저항 측정을 위해 간 조직 내에 삽입 한 전극의 끝이 세포외액에 위치한다는 점에 착안하면, 허혈 손상 후의 간 조직 생체 전기 저항의 증가는 세포외액 내의 전해질(이온) 의 감소에 기인한다고 유추할 수 있겠다. 세포막의 $\mathrm{Na}^{+}-\mathrm{K}^{+}$펌프는 $\mathrm{ATP}$ 를 소모하면서 3 개의 $\mathrm{Na}^{+}$을 세포 외로 보내고 2 개의 $\mathrm{K}^{+}$을 세 포 안으로 유입하여, 세포 내외의 삼투압을 조절하는 기능을 한다 [19]. 허혈 손상 중 간 세포 내의 ATP의 감소가 세포막 $\mathrm{Na}^{+}-\mathrm{K}^{+}$펌프 의 기능 이상을 초래하여, 세포외 액의 $\mathrm{Na}^{+}$이온 농도를 감소시키 고, 이로 인해 간 조직의 생체 전기 저항이 상승한다고도 추론 하였 고, 추가 적인 실험을 실시하여 이를 증명하였다(Fig. 8, 9)[14].

조직이 허헐 상태에 빠지면 미세 혈관벽 평활근의 수축, 혈관 내 피 세포의 변성, 혈소판과 백혈구의 용질 및 혈전의 생성, vasoactivity mediators의 생성에 의해 미세 순환 장애가 일어나며 세포 내 구조물의 변성이 일어나 조직은 손상을 받게 된다[16,17]. 그러나 2 시간 동안의 허혈 손상 중 30 분 간격으로 측정한 지방 대사율에서 도 큰 차이점을 발견 하지 못하였고(Fig. 5), 30분 간격으로 관찰한 광학현미경 소견에서 뚜렷한 차이점을 발견 할 수가 없었다(Fig. 6). 이를 미루어 보아 간 조직은 허혈 손상에는 비교적 잘 견딜 수 있는 것으로 결론 내릴 수 있었다.

수술 중에 간의 손상 여부 및 간 조직의 생존력을 실시간 또는 조 기에 확인할 수 있다면, 적절한 처치로 수술의 성공률을 높일 수 있 을 것이다. 또한 간 조직의 생체 전기 저항의 변화를 이용하여 간 조 직의 생존력을 추정할 수 있다면, 이는 최소한의 침습적인 방법으 로 간이식 및 경화간의 절제술 중 간 조직의 허혈 및 재관류 손상정 도를 실시간 모니터 할 수 있는 방법이 될 수 있을 것으로 사료된다.

본 실험들에서 허혈 유도 후 생체 전기 저항의 지속적인 상승, 재 관류 후의 감소 및 1 시간 전후의 plateau를 형성하는 경향으로 미루 어 보아, 허혈 시 간 조직 내의 생체 전기 저항의 측정은 수술 중 간 세포의 손상정도를 추정할 수 있는 지표로 응용될 수 있을 것으로 판단되며[20-22], 이를 증명할 지속적인 연구가 필요할 것으로 생각 된다.

\section{결 론}

간의 허혈 재관류 손상 시 생체 전기 저항의 변화를 측정함으로 써 간의 손상 정도를 어느 정도 예측할 수 있을 것으로 판단되며, 변화의 원인은 세포외액의 전해질의 변화임을 실험을 통하여 증명 하였다.

\section{REFERENCES}

1. Conn HO. A peek at the Child-Turcotte classification. Hepatology 1981; 1:673-6.
2. Pelton JJ, Hoffman JP, Eisenberg BL. Comparison of liver function tests after hepatic lobectomy and hepatic wedge resection. Am Surg 1998;64: 408-14.

3. Shoup M, Gonen M, D’Angelica M, Jarnagin WR, DeMatteo RP, Schwartz $\mathrm{LH}$, et al. Volumetric analysis predicts hepatic dysfunction in patients undergoing major liver resection. J Gastrointest Surg 2003;7:325-30.

4. Zoli M, Marchesini G, Melli A, Viti G, Marra A, Marrano D, et al. Evaluation of liver volume and liver function following hepatic resection in man. Liver 1986;6:286-91.

5. Imamura H, Sano K, Sugawara Y, Kokudo N, Makuuchi M. Assessment of hepatic reserve for indication of hepatic resection: decision tree incorporating indocyanine green test. J Hepatobiliary Pancreat Surg 2005;12: 16-22.

6. Haemmerich D, Ozkan R, Tungjitkusolmun S, Tsai JZ, Mahvi DM, Staelin ST, et al. Changes in electrical resistivity of swine liver after occlusion and postmortem. Med Biol Eng Comput 2002;40:29-33.

7. Sasaki E, Hirose H, Ito H, Bando M, Senga S. Dielectric spectrogram for instantaneous evaluation of ischemic injury of the liver. ASAIO J 1995; 41:M356-9.

8. Harms J, Schneider A, Baumgartner M, Henke J, Busch R. Diagnosing acute liver graft rejection: experimental application of an implantable telemetric impedance device in native and transplanted porcine livers. Biosens Bioelectron 2001;16:169-77.

9. Gheorghiu M, Gersing E, Gheorghiu E. Quantitative analysis of impedance spectra of organs during ischemia. Ann N Y Acad Sci 1999;873:6571.

10. Faes TJ, van der Meij HA, de Munck JC, Heethaar RM. The electric resistivity of human tissues $(100 \mathrm{~Hz}-10 \mathrm{MHz})$ : a meta-analysis of review studies. Physiol Meas 1999;20:R1-10.

11. Khan HA. Bioluminometric assay of ATP in mouse brain: Determinant factors for enhanced test sensitivity. J Biosci 2003;28:379-82.

12. Kim J-Y, Koves TR, Yu G-S, Gulick T, Cortright RN, Dohm GL, et al. Evidence of a malonyl-CoA-insensitive carnitine palmitoyltransferase I activity in red skeletal muscle. American Journal of Physiology-Endocrinology And Metabolism 2002;282:E1014-22.

13. Grubb BR, Chadburn JL, Boucher RC. In vivo microdialysis for determination of nasal liquid ion composition. Am J Physiol Cell Physiol 2002; 282:C1423-31.

14. Cui ML, Ahn HS, Kim JY, Lee DS, Kim HJ, Yun SS. Impaired Cation Transport May Lead to Bioelectrical Impedance Changes during Hepatic Ischemia. Journal of the Korean Surgical Society 2010;78:390-7.

15. Champion HR, Jones RT, Trump BF, Decker R, Wilson S, Miginski M, et al. A clinicopathologic study of hepatic dysfunction following shock. Surg Gynecol Obstet 1976;142:657-63.

16. Kaiho T, Miyazaki M, Ito H, Ambiru S, Shimizu H, Togawa A, et al. Reduced hepatic functional reserve in cirrhosis and obstructive jaundice with special reference to histological morphometric analysis and galactose elimination capacity. Eur Surg Res 1996;28:333-40.

17. Nauta RJ, Tsimoyiannis E, Uribe M, Walsh DB, Miller D, Butterfield A. The role of calcium ions and calcium channel entry blockers in experimental ischemia-reperfusion-induced liver injury. Ann Surg 1991;213: 137-42.

18. Grimnes S, Martinsen O. Bioimpedance and Bioelectricity Basics. . In: Academic Press, New York; 2000:99-101.

19. Arthur C, Guyton M, Hall J. Textbook of medical physiology. WB Saunders, Philadelphia 2000:874-5.

20. Cho YS, Yun SS, Shin HJ, Ahn HS, Lee DS, Kim HJ. Significance of bioelectrical impedance during ischemia-reperfusion injury in the rabbit's liver. Korean Journal of Hepato-Biliary-Pancreatic Surgery 2006;10:29- 
33.

21. Cui ML, Ahn HS, Kim JY, Shin HJ, Lee DS, Kim HJ, et al. Bioelectrical impedance may predict cell viability during ischemia and reperfusion in rat liver. J Korean Med Sci 2010;25:577-82.
22. Park SH, Yun SS, Lee DS, Kim HJ, Choi JH, Kim JY. Estimation of liver cell viability after ischemia and reperfusion injury in rat liver. Journal of the Korean Surgical Society 2007;73:1-7. 